\title{
SMALL SIDED GAMES VS REPEATED SPRINT TRAINING EFFECTS ON AGILITY IN FASTING BASKETBALL PLAYERS
}

\author{
JOGOS REDUZIDOS VS SPRINTS REPETIDOS TREINAMENTO EFIETOS NA AGILIDADE EM JOGADORES \\ DEBASQUETEEM JEJUM
}

Original Articie

ARTIGO ORIGINAL

Artículo Original

\section{JUEGOS REDUCIDOS VS SPRINTS REPETIDOS ENTERNAMIENTO EFECTOS EN LA AGILIDAD EN JUGADORES DEBALONCESTOENAYUNAS}

\begin{abstract}
Seifeddine Brini ${ }^{1,2}$ (ID (Physical Education Professional) Nejmeddine Ouerghi' (DD (Physical Education Professional) Anissa Bouassida' (ID) (Physical Education Professional)
\end{abstract}

1. University of Jendouba, Research Unit, Sportive Performance and Physical Rehabilitation, High Institute of Sports and Physical Education of Kef, Kef, Tunisia. 2. University of Carthage, 7021 Zarzouna, Faculty of Sciences of Bizerte, Bizerte, Tunisia.

\section{Correspondence:}

Seifeddine Brini.

Research Unit, Sports Performance and Physical Rehabilitation, High Institute of Sports and Physical Education of Kef, Kef, Tunisia. bseifeddine15@gmail.com

\begin{abstract}
Introduction: The coinciding of month of Ramadan with international basketball competitions could affect players' performance. Objective: This field investigation examined the impacts of a basic training program in small-sided games and repeated sprint ability during intermittent fasting for Ramadan (R) and one month after Ramadan (AR) [control month] on body composition, agility and lower limb power. Methods: Sixteen basketball players (age, $23.4 \pm 2.3$ years) performed two training programs [small-sided games (SSG) and repeated sprint ability (RSA)] during R and AR, interrupted by fifteen days of total recovery. The players were randomly allocated to two groups ( $G_{S S G}, n=8$ and $G_{R S A}, n=8$ ). Body composition, agility T test, squat jump (SJ) test, countermovement jump (CMJ) test and five-jump (FJT) test performances were measured on four occasions: before R (P1) and at the end of $R(P 2)$,as well as before AR (P3) and at the end of AR (P4). Results: The results showed that body mass $(\mathrm{BM})$, body mass index (BMI) and body fat (BF \%) decreased significantly at the end of $R$ for both groups (all $\mathrm{p}$ $<0.001)$. Moreover, the performances in the agility T test, SJ test, CMJ test and FJT test improved significantly at the end of $R$ for both groups $(p<0.001$ and $p<0.01)$. Also, by comparing $R$ with the control month, we recorded significantly better agility and FJT performances in the R month $(p<0.001)$. Conclusions: This study indicated that Ramadan combined with RSA and SSG training may improve agility and lower limb power, enabling coaches and physical trainers to choose between these two training modalities, depending on the training objectives. Level of evidence Il; Diagnostic Studies - Investigating a diagnostic test.
\end{abstract}

Keywords: Training; Physical performance; Body composition.

\section{RESUMO}

Introdução: A coincidência do mês do Ramadã e as competições internacionais de basquetebol pode influenciar o desempenho dos jogadores. Objetivo: Esta investigação de campo examinou os impactos do programa de treinamento básico em jogos reduzidos e capacidade de sprints repetidos no jejum intermitente durante o Ramadã (R) e um mês após o Ramadã (AR) [mês controle] na composição corporal, agilidade e força dos membros inferiores. Métodos: Dezesseis jogadores de basquetebol (idade, 23,4 2,3 anos) realizaram dois programas de treinamento [jogos reduzidos (SSG) e capacidade de sprints repetidos (RSA)] durante o $R$ e $A R$, interrompidos por quinze dias de recuperação total. Os jogadores foram alocados randomicamente em dois grupos (GSSG, $n=8$ e GRSA, $n=8$ ). A composição corporal, o teste T de agilidade, o teste de salto vertical sem contramovimento (SJ, squat jump), o teste do salto com contramovimento (CMJ) e o desempenho no teste de cinco saltos (FJT) foram medidos em quatro ocasiões: antes do $R(P 1)$ e no final do $R$ (P2), bem como antes de AR (P3) e no final do AR (P4). Resultados: Os resultados mostraram que a massa corporal (MC), o índice de massa corporal (IMC) e a gordura corporal (\% GC) diminuíram significativamente no final do $R$ nos dois grupos (todos $p<0,001$ ). Além disso, o desempenho no teste T de agilidade, teste SJ, teste CMJ e teste FJT melhorou significativamente no final do $R$ nos dois grupos $(p<0,001$ e $p<0,01)$. Além disso, comparando o mês do $R$ com o mês controle, registramos desempenho em agilidade e FJT significativamente maior no mês $R$ ( $p$ $<0,001)$. Conclusões: Este estudo indicou que o Ramadã combinado com treinamento RSA e SSG pode melhorar a agilidade e a força dos membros inferiores, permitindo que os treinadores e preparadores físicos escollham entre essas duas modalidades de treinamento de acordo com o objetivo do treinamento. Nível de evidência Il; Estudos Diagnósticos - Investigação de exame diagnóstico.

Descritores: Capacitação; Desempenho físico; Composição corporal.

\section{RESUMEN}

Introducción: La coincidencia del mes del Ramadán y las competiciones internacionales de baloncesto puede influir en el desempeño de los jugadores. Objetivo: Esta investigación de campo examinó los impactos del programa de entrenamiento básico en los juegos reducidos y capacidad de sprints repetidos en el ayuno intermitente durante el Ramadán (R) y un mes después del Ramadán (AR) [mes control] en la composición corporal, agilidad y fuerza de los miembros inferiores. Métodos: Dieciséis jugadores de baloncesto (edad, 23,4 $\pm 2,3$ años) realizaron dos programas de entrenamiento [juegos reducidos (SSG) y capacidad de sprints repetidos (RSA)] durante el Ry el AR, interrumpidos por 
quince días de recuperación total. Los jugadores fueron asignados aleatoriamente en dos grupos (GSSG, $n=8$ y GRSA, $n=8$ ). La composición corporal, el test T de agilidad, el test de salto vertical sin contramovimiento (SI, squat jump), el test de salto con contramovimiento (CMJ) y el desempeño en el test de cinco saltos (FJT) fueron medidos en cuatro ocasiones: antes del R (P1) y al final del R (P2), así como antes del AR (P3) y al final del AR (P4). Resultados: Los resultados mostraron que la masa corporal (MC), el indice de masa corporal (IMC) y la grasa corporal (\% GC) disminuyeron significativamente al final del $R$ en los dos grupos (todos $p<0,001$ ). Además, el desempeño del test $T$ de agilidad, el test SJ, el test CMJ y el test FJT mejoró significativamente al final del R en los dos grupos ( $p<0,001$ y $p<0,01)$. Además, al comparar el mes del R con el mes control, hemos registrado desempeño en agilidad y FJ significativamente mayor en el mes $R(p<0,001)$. Conclusiones: Este estudio indicó que el Ramadán, combinado con el entrenamiento RSAySSG, puede mejorar la agilidad y la fuerza de los miembros inferiores, permitiendo que los entrenadores y preparadores físicos escojan entre estas dos modalidades de entrenamiento de acuerdo con el objetivo del entrenamiento. Nivel de evidencia ll; Estudios Diagnósticos - Investigación de examen diagnóstico.

Descriptores: Capacitación; Desempeño físico; Composición corporal.

\section{INTRODUCTION}

Since The 2011 African Basketball Championship which took place in Madagascar, passing through the London 2012 Olympic Games to the China 2019 Basketball World Cup qualifying windows it seems that the blessed month of Ramadan crosses with the most important international basketball events which forces Muslim basketball players to be fasting, to have good performances and to continue training without diminishing the load or the intensity of their training to be in peak form on the competition day.

As we know, during Ramadan intermitting fasting (R) the dietary habits are not similar to those in other periods, so the fat, protein and carbohydrate that are consumed may vary during this month ${ }^{1}$ which will influence the body composition of Muslim athletes. ${ }^{2}$ Also, there are chronological, physiological, metabolic and hormonal changes during Ramadan, making it a unique model for prolonged intermittent fasting that affect the athletic performance. ${ }^{3-6}$ Which is difficult and stressful for athletes, as well as, imposes deficiencies for coaches and physical trainers to manage the potential of their athletes in these great events?

Also, the basketball has specific physical and physiological demands which are different from other sports practices. In this context, our study will focus on the agility and the lower limb explosive power that have been admitted among the most important physical qualities that characterize the basketball game?

In this context, many studies demonstrated that basketball is an extremely fast game that requires continual agility. ${ }^{8}$ Frequently, the game is played in short bursts of a few feet or less before a change of direction is required. Basketball players needs agility to be able to explode when penetrating to the basket, get into position to take a charge, or to catch up to an opponent after a turnover in a fast break situation. Concerning lower limb explosive power, this physical quality is also dominant in the basketball game especially during offensive and defensive rebounds and block shot.

Previous studies, have sought to found a relationship between the ability to repeat sprint (RSA) with change of direction, agility and lower limb explosive power in various team sports. ${ }^{9}$

In the same frame, other research as ${ }^{10,1}$ investigated the effect of small sided game training method on agility and the ability of change direction on sprint.

In addition, the majority of the studies that were interested in the effect of the Ramadan fasting on physical performance were made on footballers, rugby men or individual sports. ${ }^{12-14}$ however, these studies, as we have previously mentioned, are concerned with other sporting disciplines, and although there are investigations in the literature concerning the relationship between the agility and strength of the lower limbs of basketball players, these studies were conducted in unsatisfactory conditions than those exploited in our study (Ramadan intermitting fasting).

To the best of our knowledge, our study is the first to investigate intermittent fasting effects coupled with athletic training program in basketball. So our assumption was that RSA and SSG-based training programs during the month of Ramadan can affect positively the body composition agility and the lower lamb power without falling into the trap of overtraining.

In this context, our investigation will be conducted according to two main factors, that is training method (SSG vs. RSA) and Ramadan (Ramadan vs. non-Ramadan [control month]).Therefore, the purpose of the present study was to compare the effects of four-week SSG and RSA training during and after Ramadan on body composition agility and the lower lamb power in senior basketball players.

\section{METHODS}

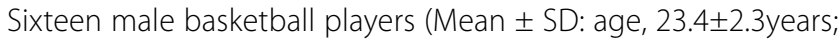
height, $1.86 \pm 0.09 \mathrm{~m}$; body mass, $78.3 \pm 11.0 \mathrm{~kg} ; \mathrm{BMl}, 22.60 \pm 1.95 \mathrm{~kg}^{-\mathrm{m}^{-2}}$ and VO2max, $51.0 \pm 2.7 \mathrm{ml} \cdot \mathrm{min}^{-1} . \mathrm{kg}^{-1}$ ) from second division (4-5 day/week, $>60 \mathrm{~min} /$ day, with a training experience of $11.8 \pm 3.9$ years) volunteered for this study. The study was conducted 2 weeks after the end of their competitive season. The subjects were assigned randomly in two groups as follows: a small-sided game group $\left(G_{s S G} ; n=8\right)$ and a repeated sprint ability group $\left(G_{R S A} ; n=8\right)$. Inclusion criteria to participate in the study were: (a) participation in at least $90 \%$ of the training sessions, (b) Muslims who were fasting during Ramadan and (c) having good health (no pain or injury reported) and not receiving any medication or other drug consumption. The study was approved by a local research ethics committee (0036/2016) and the protocol was conducted according to the Declaration of Helsinki. All participants gave their written informed consent to participate in the study.

This study aimed to examine a possible Ramadan observation effect on players submitted to RSA and SSG intervention. Players were randomly assigned in two training groups as follows: a small-sided game group $\left(G_{S S G} ;=8\right)$ and a repeated sprint ability group $\left(G_{R S A} ; n=8\right)$.The training groups (i.e., $G_{S S G}$ and $G_{\text {RSA }}$ ) performed a period of 4-week training program during Ramadan (R) and a month after Ramadan (AR), interrupted by 15 days of total recovery, with a frequency of two sessions per week. However, on the other days of week, both groups maintained their normal training routine.

Body composition, agility $T$ test, squad jump (SJ) test, countermovement jump (CMJ) test and five-jump (FJT) test performances were 
measured on four occasions: before $R(P 1)$ and at the end of $R(P 2)$, as well as before AR (P3) and at the end of AR (P4).(Figure1)

During the Ramadan phase of the study, subjects refrained from eating and drinking from dawn to sunset. Players were informed to maintain the similar nutrition and hydration routine while taking the usual Iftar and Sahur meals in proximity of every test which has been well adjusted by a nutritional expert in the field.

The Iftar meal contained a salad, a soup, spaghetti, a chicken thigh, juice and an apple, while the Sahur meal contained a salad, one yogurt, a piece of cake and a banana. The same meals were served during the control month. The period of fasting in 2016 was from 03:11 to 19:36 hours at the beginning of Ramadan to 03:16 to 19:42 hours at the end of Ramadan.

Players were part of the same basketball team and performed two training sessions of the week with SSG and RSA protocols according to their group allocation $\left(G_{S S G}\right.$ and $G_{R S A}$ ) at least 24 hours apart. The session started with a 15-min of standardized warm-up ( 5 min of low-intensity running, 5 min of dynamic stretching and 5 min of skipping) followed by the experimental training. The remaining training time was dedicated to specific basketball training.

The SSG drill used was in the form of $2 \mathrm{v} 2$ on a $(28 \mathrm{~m})$, and half-width (7.5 m) court.The2v2 format was chosen because it deemed to induce greater intensity compared to other SSG drills involving more players. $^{8,15}$ (Table 1)

The RSA consisted of three sets of $30 \mathrm{~m}$ maximal shuttle running $(15 \mathrm{~m})$ sprints repeated every 20s of passive recovery for 6 and 8 times in the first two and in last two weeks of the intervention, respectively. ${ }^{16}$ The between sets recovery was 4 min. (Table 1)

Weight (kg) was measured by an electronic balance (Pharo 200) and height (m) was measured with a stadiometer. Body mass index (BMI) was calculated as follows: BMI $\left(\mathrm{kg} / \mathrm{m}^{2}\right)$ = weight/height. ${ }^{2}$ Skinfold thickness was determined in four times at four standard sites (biceps, triceps, subscapular andsuprailiac), using a recently calibrated Harpenden caliper (Holtain Instruments, Crosswell, Pembrokeshire, UK). Body density Was calculated according to the equations of Durnin And Wormersley for men aged 20-65 years: body density $=1.1765-0.0744(\log 10 \Sigma S)$ where $\Sigma S$ is the sum of the four skinfold Readings (in $\mathrm{mm}$ ) and body fat $=(4.95 / \mathrm{D}-4.50) \times 100$ where $\mathrm{D}$ is the body density as estimated From the summed skinfolds.

The session-RPE method was used to determine the training program load, 30 min after the end of the training session for both groups [Borg's CR-10 scale]. ${ }^{17}$ Players were largely familiar with this method, which was regularly used during their training program.

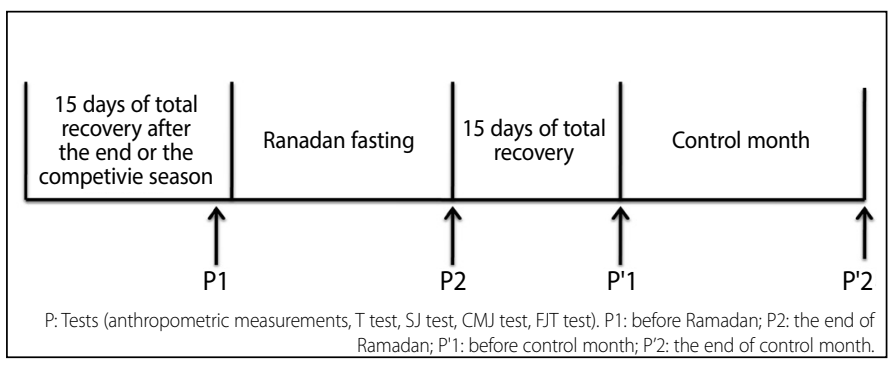

Figure 1. Representation of the experimental protocol.

Table 1.Description of the 4-weeks training program for the small-sided game (SSG) group and the repeated sprint ability group (RSA).

\begin{tabular}{c|c|c}
\hline & SSG & \multicolumn{1}{|c}{ RSA } \\
\hline Week 1 & $2 \times(2 \times 3 \mathrm{~min} 45)$ & $3 \times 6 \times 30 \mathrm{~m}(15+15) 20 \mathrm{~s} \mathrm{rec}$ \\
\hline Week 2 & $2 \times(2 \times 3 \mathrm{~min} 45)$ & $3 \times 6 \times 30 \mathrm{~m}(15+15) 20 \mathrm{~s} \mathrm{rec}$ \\
\hline Week 3 & $2 \times(3 \times 4 \mathrm{~min} 30)$ & $3 \times 8 \times 30 \mathrm{~m}(15+15) 20 \mathrm{~s} \mathrm{rec}$ \\
\hline Week 4 & $2 \times(3 \times 4 \mathrm{~min} 30)$ & $3 \times 8 \times 30 \mathrm{~m}(15+15) 20 \mathrm{~s} \mathrm{rec}$ \\
\hline SSG: small-sided games group: RSA: repeated sprint ability group: rec recovery
\end{tabular}

The T-test is the optimal test to be used in basketball to evaluate agility as it includes forward, lateral and backward running. Based on the protocol outlined by ${ }_{1}^{18}$ players sprinted from a standing point in a straight line and touched the base of a cone placed $9.14 \mathrm{~m}$ away with the right hand. Then, they side shuffled to their left without crossing their feet to another cone placed $4.57 \mathrm{~m}$ away and touched its base with their left hand. Next, they shuffled sideways to the right to the third cone placed $9.14 \mathrm{~m}$ away and touched the base with the right hand. Finally, they shuffled back to the middle cone, touched the base with the left hand and then ran backwards to the starting line. Two trials were completed and the fastest time was used for further analysis. times were recorded to the nearest one-hundredth of a second using an electronic timing system (Brower Timing Systems, Salt Lake City, UT, USA, accuracy of 0.01 seconds) placed $0.4 \mathrm{~m}$ above the ground. This test had previously demonstrated good reliability. ${ }^{19}$

Vertical jump performance was assessed using a portable Opto jump (Microgate SARL, Italy). Players performed countermovement (CMJ) and squat jumps (SJ) according to the protocol described by. ${ }^{20}$ Before testing; players performed self-administered submaximal CMJs and SJ (2N3 repetitions) as a practice and specific additional warm-up. Subjects were asked to keep their hands on their hips to prevent any influence of arm movements on the vertical jumps and to avoid coordination as a confounding variable in the assessment of the leg extensors. ${ }^{21}$ Each subject performed 3 maximal CMJs and SJs, with approximately 2 minutes recovery in between. Players were asked to jump as high as possible. The best of each type of jump was used for analysis.

The FJT test is a practical validate and alternative to estimate lower limb explosive power. ${ }^{22}$ The subject move through a series of 5 jumps strides. Feet must be together at the start and the end of the fifth jump. This test gives a good idea of the power of the lower limbs, especially the level of coordination. The absolute performance of 5 jump test is measuredin meters $(\mathrm{m})$.The subjects performed two trials with the best were retained for the analysis.

\section{Statistical analysis}

Data analyses were performed using SPSS version 17 for Windows (SPSS Inc, Chicago, II, USA). Values are presented as means \pm SD. The normality of data sets was checked using the KolmogorovSmirnov test. Compound symmetry was tested using the Mauchlin test. Two-way analysis of variance (ANOVA) with repeated measures was used to determine the differences between groups (2-condition group: $G_{S S G}$ or $G_{R S A} \times$ time of measurement: P1, P2).When a difference was found, a Bonferroni post hoc test was used. We calculated effect sizes (ES) for each output, ${ }^{23}$ and 95\% confidence interval (ESCI) when significant between-time or between-group differences were found. Paired t-test was applied to compare the body composition indices, agility, SJ, CMJ and FJT observed after 4 weeks of training during "Ramadan observance" compared to those recorded during the month after Ramadan. Statistical significance was assigned at $p$ $<0.05$ for all analysis.

\section{RESULTS}

Concerning the body composition, there was a significant main effect of Time on BM, BMI and BF\% and a significant main effect of Group only for BF\%. (Table 2)

Comparison between pre and post-training during $(R)$ showed that BM, BMI and BF\% decreased significantly $(p<0,01)$ for both groups. (Table 3)

Concerning the agility, SJ, CMJ and FJT, there was only a significant main effect of Time.(Table 4) 
Comparison between pre and post-training during (R) showed that agility, SJ, CMJ and FJT improved significantly $(p<0,01)$ for both groups. (Table 5)

Statistical analysis revealed that there were no significant differences concerning RPE scores when comparing Ramadan with the control month (AR) for both groups.

By comparing Ramadan with the control month delta variation of agility was significantly better during Ramadan. (Figure 2)

Our results revealed that FJT performance was significantly better during Ramadan in comparison with the control month. (Figure 3)

Table 2. Results of the ANOVA with $2 \times 2$ repeated measures [Group ((RSA and SSG)) $x$ Time (pre-and post-training during Ramadan)].

\begin{tabular}{c|c|c|c|c|c|c}
\hline \multirow{2}{*}{$\begin{array}{c}\text { Main effects } \\
\text { variables }\end{array}$} & \multicolumn{2}{|c|}{ Group } & \multicolumn{2}{c|}{ Time } & \multicolumn{2}{c}{ Interaction } \\
\cline { 2 - 7 } & $\mathbf{F ( 1 , 7 )}$ & $\mathrm{ES}$ & $\mathbf{F ( 1 , 7 )}$ & $\mathrm{ES}$ & $\mathbf{F}(\mathbf{1}, \mathbf{7})$ & $\mathrm{ES}$ \\
\hline $\mathrm{BM}(\mathrm{kg})$ & 0.18 & 0.03 & $3.61^{* * *}$ & 0.98 & 0.15 & 0.02 \\
\hline $\mathrm{BMI}\left(\mathrm{kg} \cdot \mathrm{m}^{-2}\right)$ & 0.03 & 0.005 & $5.97^{* * *}$ & 0.98 & 0.22 & 0.03 \\
\hline $\mathrm{BF} \%$ & $1.03^{* *}$ & 0.60 & $5.8^{* * *}$ & 0.90 & 0.001 & 0.0001 \\
\hline
\end{tabular}

BM: body mass, BMI: body mass index, BF: body fat, ES: effect size, ${ }^{* *} \mathrm{p}<0.01,{ }^{* * *} \mathrm{p}<0.001$.

Table 3.Data expressed as mean \pm SD of BM, BMI and BF\% measured in subjects during Ramadan and month after Ramadan.

\begin{tabular}{|c|c|c|c|c|c|c|c|}
\hline & & \multicolumn{3}{|c|}{ Ramadan } & \multicolumn{3}{|c|}{ Control month } \\
\hline & & P1 & P2 & ES & $P^{\prime} 1$ & $P^{\prime} 2$ & ES \\
\hline \multirow{2}{*}{ BM (Kg) } & $G_{S S G}$ & $79.5 \pm 9.87$ & $77.25 \pm 9.61^{* * *}$ & 0.36 & $81.12 \pm 9.40$ & $80.87 \pm 10.50$ & 0.52 \\
\hline & $G_{\text {RSA }}$ & $77.12 \pm 12.64$ & $74.62 \pm 11.97^{* * *}$ & 0.33 & $78.50 \pm 13.17$ & $78 \pm 13.18$ & 0.38 \\
\hline \multirow{2}{*}{$\mathrm{Ml}\left(\mathrm{kg} \cdot \mathrm{m}^{-2}\right)$} & $G_{S S G}$ & $22.67 \pm 2.35$ & $22.02 \pm 2.28^{* * *}$ & 0.10 & $23.15 \pm 2.34$ & $23.06 \pm 2.53$ & 0.16 \\
\hline & \begin{tabular}{|l|}
$G_{\text {RSA }}$ \\
\end{tabular} & $22.51 \pm 1.63$ & $21.80 \pm 1.51^{* * *}$ & 0.08 & $22.91 \pm 1.76$ & $22.77 \pm 1.85$ & 0.12 \\
\hline \multirow{2}{*}{ BF\% } & $G_{S S G}$ & $12.37 \pm 1.85$ & $11.12 \pm 1.64^{* *}$ & 0.25 & $13 \pm 2.14$ & $12.63 \pm 1.68$ & 0.26 \\
\hline & $G_{\text {RSA }}$ & $13.63 \pm 1.41$ & $12.37 \pm 1.06^{* * *}$ & 0.16 & $13.87 \pm 1.01$ & $13.25 \pm 1.16^{*}$ & 0.18 \\
\hline
\end{tabular}

G s. small-sided games group: $G$. repeated sprint ability group P1: before Ramadan $P 2$. during the $4^{\text {th }}$ week of Ramadan; $P^{\prime} 1$ : before AR; $P^{\prime} 2$ : during the $4^{\text {th }}$ week of $A R, B M$ : body mass, BMl: body mass index, BF: body fat ES: effect size, ${ }^{* *} p<0.01,{ }^{* * *} p<0.001$.

Table 4. Results of the ANOVA with $2 \times 2$ repeated measures [Group ((RSA and SSG)) xTime (pre-and post-training during Ramadan)].

\begin{tabular}{c|c|c|c|c|c|c}
\hline \multirow{2}{*}{ Main effects variables } & \multicolumn{2}{|c|}{ Group } & \multicolumn{2}{c|}{ Time } & \multicolumn{2}{c}{ Interaction } \\
\cline { 2 - 7 } & $\mathbf{F ( 1 , 7 )}$ & ES & $\mathbf{F}(\mathbf{1 , 7})$ & ES & $\mathbf{F}(\mathbf{1 , 7})$ & ES \\
\hline T test $(\mathrm{s})$ & 0.0001 & 0.0001 & $1.17^{* * *}$ & 0.94 & 4.75 & 0.40 \\
\hline $\mathrm{SJ}(\mathrm{cm})$ & 3.67 & 0.34 & $6.45^{* * *}$ & 0.90 & 1.16 & 0.14 \\
\hline $\mathrm{CMJ}(\mathrm{cm})$ & 3.14 & 0.31 & $7.6^{* * *}$ & 0.92 & 0.68 & 0.09 \\
\hline FJT $(\mathrm{m})$ & 0.43 & 0.06 & $1.69^{* *}$ & 0.70 & 0.86 & 0.11 \\
\hline
\end{tabular}

T test: agility $T$ test; SJ: squad jump test; CMJ: countermovement jump test; FJT: five jump test; $E S:$ effect size; ${ }^{* *} p<0.01, * * * 0<0.001$

Table 5. Data expressed as mean \pm SD of agility, SJ, CMJ and FJT performances measured in subjects during Ramadan and month after Ramadan.

\begin{tabular}{c|c|c|c|c|c|c|c}
\hline & & \multicolumn{3}{|c|}{ Ramadan } & \multicolumn{3}{c}{ Control month } \\
\hline \multirow{2}{*}{ T test (s) } & & P1 & P2 & ES & P'1 $^{\prime}$ & P'2 $^{\prime}$ & ES \\
\cline { 2 - 8 } & $G_{\text {SSG }}$ & $10.20 \pm 0.89$ & $9.86 \pm 0.91^{* * *}$ & 0.04 & $10.14 \pm 0.80$ & $10.04 \pm 0.81$ & 0.05 \\
\hline \multirow{2}{*}{ SJ (cm) } & $G_{\text {RSA }}$ & $10.4 \pm 0.98$ & $9.92 \pm 0.91^{* * *}$ & 0.03 & $10.08 \pm 0.91$ & $9.98 \pm 0.92^{* *}$ & 0.18 \\
\cline { 2 - 8 } & $G_{\text {SSG }}$ & $37.25 \pm 6.31$ & $41.37 \pm 6.82^{* * *}$ & 0.54 & $38.50 \pm 5.88$ & $40.25 \pm 6.58^{* *}$ & 0.52 \\
\hline \multirow{2}{*}{ CMJ (cm) } & $G_{\text {RSA }}$ & $32.75 \pm 4.97$ & $37.38 \pm 5.90^{* * *}$ & 0.62 & $34,3 \pm 5.94$ & $35.76 \pm 5.03$ & 0.73 \\
\cline { 2 - 8 } & $G_{S S G}$ & $40.5 \pm 6.98$ & $43.75 \pm 6.65^{* * *}$ & 0.27 & $39.50 \pm 5.92$ & $40.50 \pm 607$ & 1.01 \\
\hline \multirow{2}{*}{ FJT (m) } & $G_{\text {RSA }}$ & $35.37 \pm 4.95$ & $38.25 \pm 5.52^{* *}$ & 0.70 & $35.76 \pm 5.26$ & $37.38 \pm 5.32^{*}$ & 0.59 \\
\cline { 2 - 8 } & $G_{S S G}$ & $7.23 \pm 0.55$ & $7.50 \pm 0.51^{* *}$ & 0.08 & $7.35 \pm 0.47$ & $7.43 \pm 0.53$ & 0.05 \\
\cline { 2 - 8 } & $G_{\text {RSA }}$ & $7.45 \pm 0.50$ & $7.67 \pm 0.45^{* *}$ & 0.04 & $7.57 \pm 0.7$ & $7.68 \pm 0.45$ & 0.05 \\
\hline
\end{tabular}

$\mathrm{G}_{\text {sSG: }}$ : Small-sided games group; $\mathrm{G}_{\mathrm{RSA}}$ : repeated sprint ability group; P1: before Ramadan; P2: during the $4^{\text {th }}$ week of Ramadan; $P^{\prime} 1$ : before AR; $P^{\prime} 2$ : during the $4^{\text {th }}$ week of AR; T test: agility $T$ test; $S$ J: squad jump test; $C M J$ : countermovement jump test; FJT: five jump test; ES: effect size; ${ }^{* *} p<0.01,{ }^{* * *} p<0.001$.

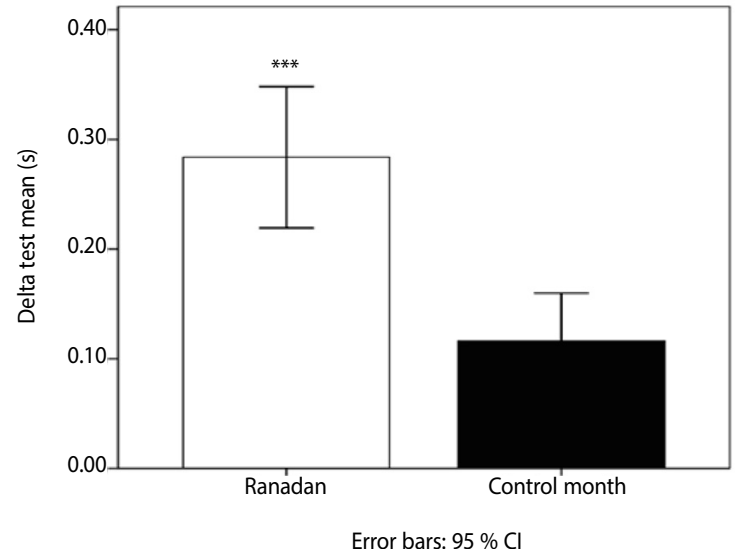

Figure 2. Representation of Delta T test mean performance during Ramadan and the control month. $(p<0.001) .(n=16)$

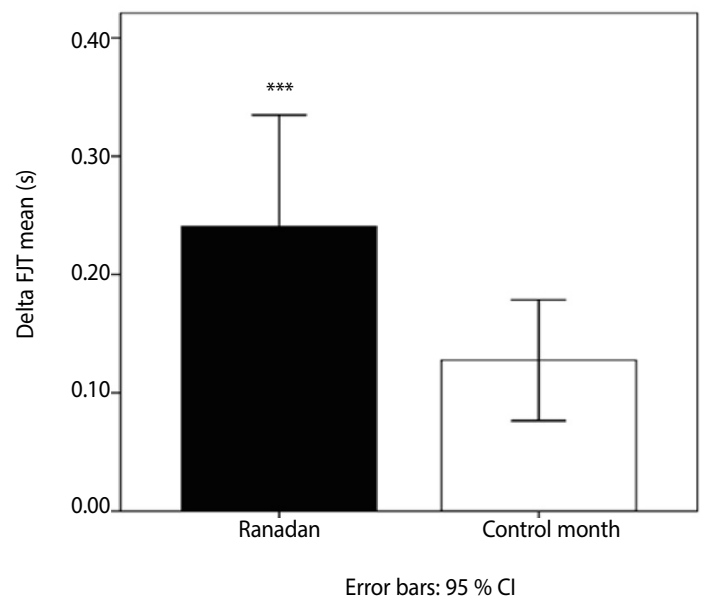

Figure 3. Representation of Delta FJT test mean performance during Ramadan and the control month. $(p<0.001)$. $(n=16)$.

\section{DISCUSSION}

According to the two main factors in our investigation, which are the training method (SSG vs. RSA) and Ramadan (Ramadan vs. non-Ramadan [control month]), the findings have shown that the majority of the body composition indices of male senior basketball player submitted to additional (SSG vs. RSA) decrease at the end of Ramadan. Also, agility and lower limb power are improved for both groups.

In the present investigation, BM, BMl and BF\% decreased significantly for both groups SSG and RSA at the end of Ramadan which is in the same line with the studies conducted by. 24,14,25 It has been suggested that this decline in body weight could be attributed to a decrease in fluid intake and hypo hydration with little loss of body fat because Ramadan fasting is characterized by alterations in meal schedule and frequency. Also, meals are exclusively nocturnal and less frequent; hence this may affect energy and nutrient intake.

In this context, it has previously been shown that there is an increase in saturated fat intake during Ramadan among the Tunisian population. 26,27 These decreases may also be partly a function of increased utilization of stored body fat. Such a finding has been reported in previous investigations. ${ }^{28,29}$ However, the findings of this study do not support some previous research which showed no body mass changes might be observable among athletes during Ramadan fasting ${ }^{30,31}$ which could be attributed to a common belief that athletes are likely to overcompensate their food and fluid intake during Ramadan fasting. 
Concerning agility and lower limb power, our investigation showed that the both physical qualities were improved after four weeks of intermitting fasting combined with SSG and RSA in male senior basketball player. Moreover, these performances were significantly higher during Ramadan in comparison with the control month. This improvement can be done according to two main factors, the first is manifested by the significant loss of body mass and BF\% at the end of Ramadan and of course this decrease will promote a body lightening that will make the athlete more agile and the decrease in body weight constraint will improve the ability of the lower limbs to jump; in second place we cannot neglect also the important effect of our two training program (RSA and SSG) which resulted a certain improvement during the phase of the control month.

On the other hand, the results found in our study are different from those indicated by previous studies ${ }^{32-34,25,5}$ as among these authors there are those who have not found significant differences in agility and jump performance, as well as, others scored a decrease in performance at the end of Ramadan.A possible explanation for these results according to this authors was the decrease of the calorie intake, sleep hours and the time of the day which they did their training sessions.
Finally, the present study has some limitations. First, the intervention program was of short duration. Second, the relatively small number of participants may have underpowered the study, Third, we did not use a control group which was substituted by a control month.

\section{CONCLUSION}

This study showed that senior basketball player can be able to continue their daily training regimen during Ramadan without falling into the trap of overtraining with carefully prescribed calibrations. Also; it revealed that our modeling in basketball training associated with Ramadan intermitting fasting may improve the agility and the lower limb power according to the decrease in body composition in male senior basketball players.

\section{ACKNOWLEDGEMENTS}

The authors would like to acknowledge with considerable gratitude all those who volunteered to take part in this study.

All authors declare no potential conflict of interest related to this article

AUTHORS' CONTRIBUTIONS: Each author made significant individual contributions to this manuscript. SB: writing, data analysis, statistical analysis, intellectual concept and drafting of the entire research project; NO: statistical analysis, data analysis and revision; AB: revision, statistical analysis, intellectual concept and writing. All authors approved the final version of the manuscript

\section{REFERENCES}

1. Gumaa KA, Mustafa, KY, Mahmoud NA, Gader AM. The effects of fasting in Ramadan Serum uric acid and lipid concentrations. Br J Nutr. 1978;40(3):573-81.

2. Trabelsi K, El Abed K, Trepanowski JF, Stannard SR, Ghlissi Z, Ghozzi H, et al. Effects of ramadan fasting on biochemical and anthropometric parameters in physically active men. Asian J Sports Med. 2011;2(3): 134-44.

3. Leiper JB, MollaAM, Molla AM. Effects on health of fluid restriction during fasting in Ramadan. Eur J ClinNutr. 2003;57(Suppl 2):S30-8.

4. Roky R, Houti I, Moussamih S, Qotbi S, Aadil N. Physiological and chronobiological changes during Ramadan intermittent fasting. Ann NutrMetab. 2004;48(4):296-303.

5. Chaouachi A, Leiper JB, Souissi N, Coutts AJ, Chamari K. Effects of Ramadan Intermittent Fasting on Sports Performance and Training: A Review. Int J Sports Physiol Perform. 2009;4(4):419-34.

6. Mujika I, Chaouachi A, Chamari K. Precompetition taper and nutritional strategies: special reference to training during Ramadan intermittent fast. Br J Sports Med. 2010;44(7):495-501.

7. Ben Abdelkrim N, El Fazaa S, ElAti J. Time-motion anlysis and physiological data of elite under-19-year ald basket-ball players during competition. Br J Sport Med. 2007;41(2):69-75.

8. Castagna C, Manzi V, D'Ottavio S, Annino G, Padua E, Bishop D. Relation between maximal aerobic power and the ability to repeat sprints in young basketball players. J Strength Cond Res. 2007;21(4): 1172-6.

9. Wong deIP, Chan GS, Smith AW. Repeated-sprint and change-of-direction abilities in physically active individuals and soccer players: training and testing implications. J Strength Cond Res. 2012;26(9):2324-30.

10. Young $W$, Rogers $N$. Effects of small-sided game and change-of-direction training on reactive agility and change-of-direction speed. J Sports Sci. 2014;32(4):307-14.

11. Chaouachi A, Chtara M, Hammami R, Chtara H, Turki O, Castagna C. Multidirectional sprints and small-sided games training effect on agility and change of direction abilities in youth soccer.J Strength Cond Res. 2014;28(11):3121-7.

12. Hamouda O, Chtourou H, Farjallah MA, Davenne D, Souissi N, et al. The effect of Ramadan fasting on the diurnal variations in aerobic and anaerobic performances in Tunisian youth soccer players. Biol Rhythms Res. 2011;1:177-90.

13. Bouhlel E, Denguezli M, Zaouali M, Tabka Z, Shepard RJ. Ramadan fasting's effect on plasma leptin, adiponectin concentrations, and body composition in trained young men. Int J Sport Nutr Exec Metab. 2008; 18(6):617-27.

14. Chaouachi A, Chamari K, Roky R, Wong P, Mbazaa A,Bartagi Z, et al. Lipid profiles of judo athletes during Ramadan. Int. Sports Med. 2008; 29(4):282-8.

15. Delextrat A, Martinez A. Small-sided game training improves aerobic capacity and technical skills in basketball players. Int J Sports Med. 2014;35(5):385-91.

16. Attene G, Laffaye G, Chaouachi A, Pizzolato F, Migliaccio GM, Padulo J. Repeated sprint ability in young basketball players: one vs. two changes of direction (Part 2). J. Sports Sci. 2015;33(15):1553-63.

17. Foster C. Monitoring training in athletes with reference to overtraining syndrome. Med Sci Sports Exerc. 1998;30(7):1164-8.
18. Pauloe K, Madole K, Garhammer J, Lacourse M, Rozenek R. Reliability and validity of the t-test as a measure of agility, leg power, and leg speed in college-aged men and women. J Strength Cond Res. 2000; 14(4):443-50.

19. Sassi RH, Dardouri W, Yahmed MH, Gmada N, Mahfoudhi ME, Gharbi Z. Relative and absolute reliability of a modified agility T-test and its relationship with vertical jump and straight sprint. J Strength Cond Res. 2009;23(6):1644-51.

20. Bosco C, Luhtanen P, Komi PV. A simple method for measurement of mechanical power in jumping Eur J ApplPhysiolOccup Physiol.1983; 50(2):273-82.

21. Bosco C, Belli A, Astrua M, Tihanyi J, Pozzo R, Kellis S, et al. A dynamometer for evaluation of dynamic muscle work. Eur J ApplPhysiolOccup Physiol. 1995;70(5):379-86.

22. Chamari K, Chaouachi A, Hambli M, Kaouech F, Wisløff U, Castagna, C. The five-jump test for distance as a field test to assess lower limb explosive power in soccer players. J Strength Cond Res. 2008;22(3):944-50

23. Cohen J. Eta-squared and partial eta-squared in fixed factor ANOVA designs. EducPsychol Measurement 1973;33:107-12.

24. Bouhlel E, Salhi Z, Bouhlel H, Mdella S, Amamou A, Zaouali M, et al. Effect of Ramadan fasting on fuel oxidation during exercise in trained male rugby players. Diabetes Metab.2006;32(6):617-24.

25. Memari AH, Kordi R, Panahi N, Nikookar LR, Abdollahi M, Akbarnejad A. Effect of Ramadan fasting on body composition and physical performance in female athletes. Asian J Sports Med. 2011;2(3):161-6.

26. Beltaifa L, Bouguerra R, Ben Slama C, Jabrane H, El-Khadhi A, Ben Rayana MC, et al.Food intake and anthropometrical and biological parameters in adult Tunisians during fasting at Ramadan. East Mediterr Health J. 2002;8(4-5):603-11.

27. El Ati J, Beji C, Danguir J. Increased fat oxidation during Ramadan fasting in healthy women: an adaptive mechanism for body-weight maintenance. Am J ClinNutr. 1995;62(2):302-7.

28. Ramadan J. Does fasting during Ramadan alter body composition, blood constituents and physical performance? Med PrincPract. 2002;11(Suppl 2):41-6.

29. Aziz AR, Wahid MF, Png W, Jesuvadian CV. Effects of Ramadan fasting on 60 min of endurance running performance in moderately trained men. Br J Sports Med. 2010;44(7):516-21.

30. Faye J, Fall A, Badji L, Cisse F, Stephan H, Tine P. Effects of Ramadan fast on weight, performance and glycemia during training for resistance. Dakar Med. 2005;50(3):146-51.

31. Bahammam A. Does Ramadan fasting affect sleep? Int J ClinPract. 2006;60(12):1631-7.

32. Bouhlel H, Shephard RJ, Gmada N, Aouichaoui C, Peres G, Tabka Z, et al. Effect of Ramadan observance on maximal muscular performance of trained men. Clin J Sport Med. 2013;23(3):222-7.

33. Zerguini Y, Kirkendall D, Junge, A, Dvorak J. Impact of Ramadan on physical performance in professiona soccer players. Br J Sports Med.2007;41 (6):398-400.

34. Meckel Y, Ismaeel A, Eliakim A. The effect of the Ramadan fast on physical performance and dietary habits in adolescent soccer players. Eur J Appl Physiol. 2008;102(6):651-7. 